\title{
Effect of Heat Treatment on Microstructure and Properties of Steel
}

\author{
Huang Guiyun ${ }^{1, a, *}$, Li Yong ${ }^{1, b}$, Xiong Yakun ${ }^{2, c}$ \\ ${ }^{1}$ Beijing Polytechnic, Beijing, China \\ ${ }^{2}$ Beijing Union University, Beijing, China \\ a18801281447@163.com, bliyong0401@126.com, c1487912802@qq.com
}

Keywords: heat treatment, microstructure, properties

\begin{abstract}
The microstructure and properties of metal materials are different when treated with different heat treatment processes. In order to obtain the best performance of use, heat treatment plays an important role in fully exploiting the potential of materials and achieving maximum economic benefits. Conventional heat treatment usually refers to annealing, normalizing, quenching and tempering. Different heat treatment processes were carried out for selected steel 45 steel and T12 steel. The changes in metallographic structure of materials caused by different processing technology were systematically observed and their properties were tested. The hardness is analyzed from the aspects of heating temperature, different cooling methods, tempering after quenching and so on, and the causes of abnormal data are explained.
\end{abstract}

\section{Introduction}

Metal heat treatment is a discipline to study the relationship between metal material composition, process and microstructure and properties. The microstructure and properties of metal materials are different when treated with different heat treatment processes. In order to get the best performance, heat treatment plays an important role in fully excavating the potential of materials and achieving the greatest economic benefits.

Conventional heat treatment is usually referred to as annealing, normalizing, quenching and tempering.

In this paper, the selected steel 45 steel and T12 steel were subjected to different heat treatment processes, and the changes in metallographic structure of the materials caused by different treatment processes were systematically observed and tested.

According to the needs of actual organization and performance, the formulation of heat treatment process includes: determination of heating temperature, determination of heating and heat preservation time and selection of cooling medium.

\section{Determination of heating temperature}

The basis for determining the quenching heating temperature is the critical point corresponding to the composition of the steel. For hypoeutectoid steel, eutectoid steel and hypereutectoid steel, there are different process principles for determining the quenching temperature:

The quenching temperature of the subeutectoid steel is:Ac3 $+\left(30 \sim 50^{\circ} \mathrm{C}\right)$ 。 If the quenching temperature is too high, the martensite structure after quenching will be significantly thickened, which will deteriorate the mechanical properties of the material. When the quenching temperature is lower than Ac3, the quenched structure will contain undissolved free ferrite, so that the hardness after quenching is lowered.However, according to recent studies, it has been found that the subtemperature quenching (the insertion of one or several times below the Ac3 point temperature between the common quenching and tempering) will improve the toughness of the material, inhibit the reversible temper brittleness of the steel, and reduce the critical embrittlement temperature more expensive, so the subtemperature quenching is a new process of strengthening and toughening.Table 1 lists the critical points of some common steels for reference. 
The quenching temperature of eutectoid steel and eutectoid steel is:Ac1 $+\left(30 \sim 50^{\circ} \mathrm{C}\right)$ 。 Controlling the amount of secondary carbides dissolved into the austenite (ie, controlling the quenching heating temperature) can control the morphology of the martensite. When the temperature is too high, if the temperature exceeds the Acm point, the martensite tissue will be thick, and the amount of retained austenite will increase significantly and the mechanical performance will be poor. At the same time, it also increases the quenching stress, which increases the tendency of deformation and cracking.

Table 1 Critical point of common carbon steel

\begin{tabular}{|c|c|c|c|c|c|c|c|}
\hline \multirow{2}{*}{$\begin{array}{c}\text { Steel } \\
\text { number }\end{array}$} & \multicolumn{3}{|c|}{$\begin{array}{c}\text { Critical point temperature } \\
\text { (approximate) }\end{array}$} & \multirow{2}{*}{$\begin{array}{c}\text { Steel } \\
\text { number }\end{array}$} & \multicolumn{3}{|c|}{$\begin{array}{c}\text { Critical point temperature } \\
\text { (approximate) }\end{array}$} \\
\cline { 2 - 3 } & Ac1 & Ac3 & Acm & & Ac1 & Ac3 & Acm \\
\hline 20 & 735 & 855 & & T8 & 730 & & \\
\hline 30 & 732 & 813 & & T10 & 730 & & 800 \\
\hline 45 & 724 & 780 & & T12 & 730 & & 820 \\
\hline 60 & 727 & 766 & & $40 \mathrm{Cr}$ & 743 & & \\
\hline $\mathrm{T} 7$ & 730 & 770 & & & & & \\
\hline
\end{tabular}

\section{Determination of heating and holding time}

The theoretical time for quenching and heating is determined according to the following formula: $\tau=\tau_{1}+\tau_{2}+\tau_{3}$

Among them:

$\tau$ - Total heating time

$\tau_{1}$ — The time required to reach the specified temperature after the work of the workpiece is entered.

$\tau_{2}$ — The time when the workpiece is fired (when the surface temperature of the workpiece reaches the center of the body).

$\tau_{3}$ - Time needed for an organization to change

In the production practice, the experience data of box type resistance furnace heating time are listed in Table 2. When calculating, the smallest size direction of workpiece is selected.

Table 2 Time required for different heating temperatures in box-shaped resistance furnace

\begin{tabular}{|c|c|c|c|}
\hline \multirow[b]{2}{*}{$\begin{array}{c}\text { Heating } \\
\text { temperature }\left({ }^{\circ} \mathrm{C}\right)\end{array}$} & \multicolumn{3}{|c|}{ Heating time } \\
\hline & $\begin{array}{c}\text { Round steel } \\
\text { (minutes/mm) }\end{array}$ & $\begin{array}{c}\text { Square steel } \\
\text { (minutes/mm) }\end{array}$ & $\begin{array}{c}\text { Sheet steel } \\
\text { (minutes/mm) }\end{array}$ \\
\hline 600 & 2.0 & 3.0 & 4.0 \\
\hline 700 & 1.5 & 2.2 & 3.0 \\
\hline 800 & 1.0 & 1.5 & 2.0 \\
\hline 900 & 0.8 & 1.2 & 1.6 \\
\hline 1000 & 0.4 & 0.6 & 0.8 \\
\hline
\end{tabular}

\section{The selection of quenching medium:}

After determining the quenching heating temperature and heating and holding time, it is necessary to select the appropriate cooling medium to achieve the desired technological purpose. The basis is as shown in Figure 1 below. 


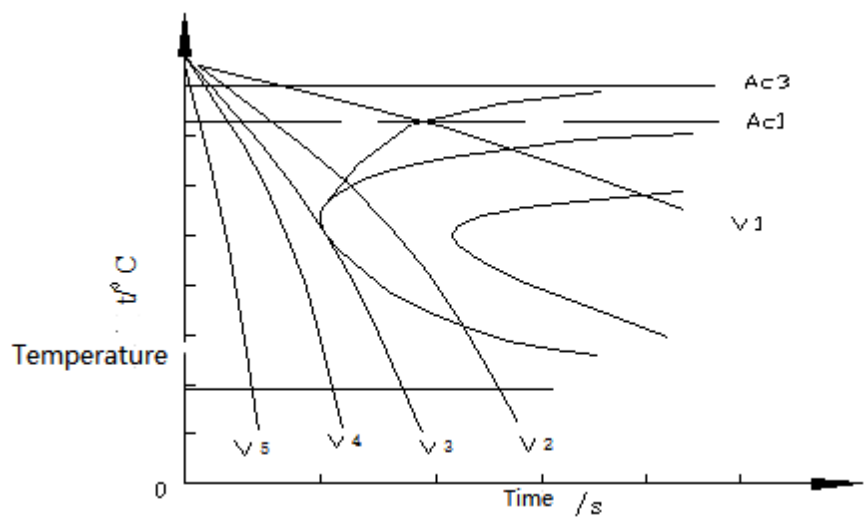

Figure 1 Schematic diagram of the quenching medium cooling curve (the title does not seem right, CCTT diagram)

Figure 1 shows that a single martensite can be obtained by cooling only at a critical cooling rate of V3 at a critical cooling rate (such as V4, V5). (in theory, the retained austenite is also contained in the tissue). When the cooling rate is less than V3 (such as V1 and V2), martensite (V1) or non martensite (V2) may not be obtained after quenching. Therefore, the choice of quenching medium is first to make the cooling speed greater than the critical cooling rate of V3, and then select the smaller deformation and cracking tendency. The ideal quenching medium should be: in the most easily decomposed temperature range of the supercooled austenite (the tip of the nose of the $\mathrm{C}$ curve) has a strong cooling capacity to suppress the decomposition of the supercooled austenite. And near Ms, there is a relatively mild cooling rate. Such quenching medium has higher quenching and cooling speed without causing excessive quenching stress. Therefore, the quenching medium should be selected according to the $\mathrm{C}$ curve of the specific material. Table 3 shows the cooling capacity of some common cooling media in different temperature zones.

Table 3 Common quenching medium cooling capacity

\begin{tabular}{|c|c|c|}
\hline \multirow{2}{*}{ Quenching medium } & \multicolumn{2}{|c|}{ Cooling rate $\left({ }^{\circ} \mathrm{C} / \mathrm{sec}\right)$} \\
\cline { 2 - 3 } & $\begin{array}{c}\text { In the interval of } \\
550 \sim 650^{\circ} \mathrm{C}\end{array}$ & $\begin{array}{c}\text { In the range of } \\
200 \sim 300^{\circ} \mathrm{C}\end{array}$ \\
\hline Water $\left(18^{\circ} \mathrm{C}\right)$ & 600 & 270 \\
\hline Water $\left(26^{\circ} \mathrm{C}\right)$ & 500 & 270 \\
\hline Water $\left(50^{\circ} \mathrm{C}\right)$ & 100 & 270 \\
\hline Water $\left(74^{\circ} \mathrm{C}\right)$ & 30 & 200 \\
\hline $\begin{array}{c}10 \% \text { aqueous caustic } \\
\text { soda18 } 8^{\circ} \mathrm{C}\end{array}$ & 1200 & 300 \\
\hline $\begin{array}{c}10 \% \text { sodium chloride } \\
\text { aqueous solution } 18^{\circ} \mathrm{C}\end{array}$ & 1100 & 300 \\
\hline $\begin{array}{c}10 \% \text { soda aqueous } \\
\text { solution18 }\end{array}$ & 800 & 270 \\
\hline Distilled water & 250 & 200 \\
\hline Oil emulsion & 70 & 200 \\
\hline Soap water & 30 & 200 \\
\hline Mineral oil & 100 & 20 \\
\hline HG & 500 & 130 \\
\hline Copper plate & 60 & 30 \\
\hline iron plate & 35 & 15 \\
\hline
\end{tabular}

The martensite obtained after quenching of steel has high hardness, strength and high quenching stress, and is usually rarely delivered directly. Therefore, quenching parts generally must be tempered in time, otherwise it will often cause deformation, cracking, and even the phenomenon of 
part collapse.

According to the different performance of the parts, the quenching parts are classified into low temperature tempering $\left(<250^{\circ} \mathrm{C}\right)$, medium temperature tempering $\left(350 \sim 500^{\circ} \mathrm{C}\right)$ and high temperature tempering $\left(>500^{\circ} \mathrm{C}\right)$. As the tempering temperature increases, the hardness and strength indicators gradually decrease, while the plasticity and toughness indicators gradually increase, and most of the quenching stress is reduced or eliminated.

The holding time of tempering is usually set to $0.5 \sim 2$ hours according to the empirical data, combined with the material and size of the specific workpiece.

In this paper, through the normal quenching and tempering process of 45 steel and T12 steel, and the actual operation, some mechanical properties are determined. Combined with the observation of the microstructure of 45 steel and T12 steel after different heat treatment processes, the properties are determined. The law of its organization and performance changes.

\section{Hardness test and analysis}

After the sample was cooled, the two planes parallel to each other were smoothed and light with coarse sand paper (No. 200 and 400), and the hardness value was measured by the HR-150A Rockwell hardness tester. As the sample is subjected to heat treatment and has high hardness, the test is carried out in HRC, and the test results are recorded in Table 4.

Table 4 Hardness of the sample after different heat treatment processes

\begin{tabular}{|c|c|c|c|c|c|c|c|}
\hline $\begin{array}{c}\text { Sample } \\
\text { Numbering }\end{array}$ & $\begin{array}{l}\text { Sample heat } \\
\text { treatment } \\
\text { process }\end{array}$ & $\begin{array}{c}\text { Steel } \\
\text { number }\end{array}$ & $\begin{array}{l}\text { average } \\
\text { value }\end{array}$ & $\begin{array}{l}\text { Sample } \\
\text { Numbering }\end{array}$ & $\begin{array}{c}\text { Sample heat treatment } \\
\text { process }\end{array}$ & $\begin{array}{c}\text { Steel } \\
\text { number }\end{array}$ & $\begin{array}{l}\text { average } \\
\text { value }\end{array}$ \\
\hline \multirow{2}{*}{1} & \multirow{2}{*}{$\begin{array}{l}\text { Normal } \\
\text { heating, water } \\
\text { cooling }\end{array}$} & 45 & 60.57 & \multirow{2}{*}{5} & \multirow{2}{*}{$\begin{array}{c}\text { Normal heating, water } \\
\text { cooling, } \\
200^{\circ} \mathrm{C} \text { tempering }\end{array}$} & 45 & 50.40 \\
\hline & & T12 & 66.8 & & & T12 & 64.1 \\
\hline \multirow{2}{*}{2} & \multirow{2}{*}{$\begin{array}{l}\text { Normal } \\
\text { heating, oil } \\
\text { cooling }\end{array}$} & 45 & 33.57 & \multirow{2}{*}{6} & \multirow{2}{*}{$\begin{array}{l}\text { Normal heating, water } \\
\text { cooling, } \\
\text { Tempering at } 400^{\circ} \mathrm{C}\end{array}$} & 45 & 41.40 \\
\hline & & T12 & 40.3 & & & T12 & 48.5 \\
\hline \multirow{2}{*}{3} & \multirow{2}{*}{$\begin{array}{l}\text { Normal } \\
\text { heating, air } \\
\text { cooling }\end{array}$} & 45 & 15.73 & \multirow{2}{*}{7} & \multirow{2}{*}{$\begin{array}{c}\text { Normal heating, water } \\
\text { cooling, } \\
600^{\circ} \mathrm{C} \text { tempering }\end{array}$} & 45 & 31.10 \\
\hline & & T12 & 27 & & & T12 & 32 \\
\hline \multirow{2}{*}{4} & \multirow{2}{*}{ Unheated state } & 45 & 12.53 & \multirow{2}{*}{8} & $\begin{array}{l}760^{\circ} \mathrm{C} \text { heating, water } \\
\text { cooling }\end{array}$ & 45 & 46.13 \\
\hline & & T12 & 0.5 & & $\begin{array}{l}970^{\circ} \mathrm{C} \text { heating, water } \\
\text { cooling }\end{array}$ & T12 & 64.1 \\
\hline
\end{tabular}

(Note: Water cooling uses 10\% sodium chloride aqueous solution; oil cooling uses oil.)

(1) The effect of heating temperature on properties: quenching critical temperature is too high or too low will cause adverse effects on quenched steel. The heating temperature is low, the hardness will be insufficient; the heating temperature is too high, it will cause the overheating of the quenched steel, make the steel crack easily, the brittleness is big, and the toughness is insufficient. Therefore, during quenching, suitable quenching temperature should be selected, not the higher the temperature.

(2) The effect of cooling mode on Performance: the faster the cooling rate, the higher the hardness, the cooling rate, the brine $>$ clean water $>$ Oil $>$ air. When the cooling rate is different, the temperature of the solid state transformation is different, and the structure is very different. In general, the faster the cooling rate is, the lower the temperature of the steel is, the higher the hardness of the microstructure is obtained after the transformation. It is mainly because the lower the transition temperature, the lower the activity of the atom and the thinner the tissue, for example, the interlayer spacing of the pearlite body decreases with the decrease of the formation temperature; if the cooling rate is large enough, martensite can be changed to get martensite, and its hardness will be higher.

(3) The effect of tempering temperature on Performance: high hardness after quenching is because carbon is solid dissolved in the matrix and the atoms are arranged closely. When the 
carbides re precipitate, the atoms are not arranged closely and the hardness drops. The higher the temperature of the tempering, the more active carbon atoms, the easier the precipitation is, and the lower the hardness.

\section{Acknowledgements}

Promote the connotation construction of colleges and universities--Faculty construction--2018 mechanical engineering college research team and academic leader building

\section{References}

[1] D.C.Wang Effect of quenching temperature on Microstructure and fracture toughness of high carbon steel[J].Journal of iron and Steel Research.30(3):229-234,2018.

[2] L.Y.Qin Effect of austempering process on Microstructure and properties of high carbon steel [J].Casting technology.35 (7):1438-1440, 2014.

[3] X.Sun.Study on the influence factors of mechanical properties of engineering materials [J].Journal of Hunan City University.25 (1):199-200,2016.

[4] Y.H.Yao Relationship between hardness of martensite and carbon content in quenched carbon steel[J].Metal heat treatment.39(8):137-138,2014.

[5] C.Meng The general situation of 45 steel and the method of heat treatment [J]. China New Technologies and Products. 09:125-126, 2011.

[6] Y.Gao,L.X.Shao Study on Optimization of heat treatment process of high strength steel for automobile[J]. Hot Working Technology.14:204-207,2016.

[7] G.X.Wang Effect of heat treatment on Microstructure and properties of 45 steel [J].Chemical Engineering Design Communications.02:99-100,2016.

[8] Y.B.Liu Optimization of heat treatment process for ultra-high strength engineering structural steel[J].Hot Working Technology.22:179-182,2016.

[9] R.H.Ding Study on heat treatment process of Cr12 high carbon high chromium cold working die steel [J].Hot Working Technology.10:200-202, 2017.

[10] Z.G.Zhao and so on Study on heat treatment and properties of high speed steel with injection molding[J].Metal Materials and Metallurgy Engineering.03:29-33,2017.

[11] T.Jiang . Effect of heat treatment on Microstructure and properties of mechanical gear steel [J]. Hot Working Technology. 04:195-198, 2018.

[12] H.J.Yu and so on Effect of heat treatment process on properties of ultra high strength martensitic steel [J]. Journal of Iron and Steel Research.05:392-398, 2018. 